\title{
Senate shift bodes well for 'green' science
}

Tony Reichhardt, Washington

and Rex Dalton, San Diego

Washington underwent an upheaval last week, when Senator James Jeffords of Vermont left the Republican Party and handed control of the US Senate to the Democrats. Science is not generally seen as a battleground in the shifting political landscape. But environmental policy will now move to centre stage, which may improve funding prospects for environmental research.

The shift will see new faces in the chairs of all key Senate committees. On the subcommittee that oversees funding of the National Science Foundation and NASA, Kit Bond (Republican, Missouri) is expected to give way to Barbara Mikulski (Democrat, Maryland). Leadership of the equivalent panel for the National Institutes of Health is expected to shift from Arlen Specter (Republican, Pennsylvania) to Tom Harkin (Democrat, Iowa).

On both committees, however, it should be business as usual. An aide to Bond, for instance, notes that he and Mikulski have "a close working relationship that has produced a reservoir of good will". And according to conventional US political wisdom, science often benefits when one party controls the White House and the other the Senatespending on research is one subject on which opposing politicians can usually agree.

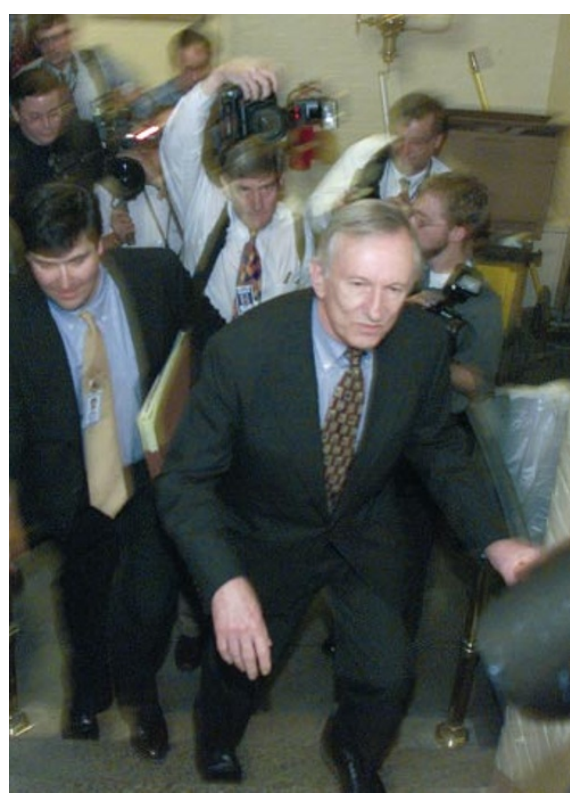

Wind of change: environmental science may find favour in the wake of James Jeffords' decision.

There could be greater implications in the shift in leadership of the subcommittee that oversees the Department of Energy's budget. Pete Domenici (Republican, New Mexico), whose state is home to the Los Alamos and Sandia National Laboratories, is expected to be replaced by Harry Reid (Democrat, Nevada). Although Reid is a supporter of science, he has been critical of cost overruns at the National Ignition Facility, a huge laser project at the Lawrence Livermore National Laboratory in California.

Reid also opposes plans to develop his state's Yucca Mountain site as a repository for nuclear waste. And this is just one of a slew of environmental and energy policy issues on which the Democratic Senate majority will battle President George W. Bush. Plans to drill for oil in Alaska's Arctic National Wildlife Refuge, for instance, are now effectively dead, with the state's two pro-drilling Republican senators, Ted Stevens and Frank Murkowski, losing respective control of the Appropriations Committee and the Energy and Natural Resources Committee.

Jeffords, sitting as an independent, has reportedly been promised the chair of the Environment and Public Works committee. Such a move will please environmentalists, who respect his stance on green issues.

One result of all these changes is expected to be greater support in the Senate for environmental science and for research into alternative energy sources, both downplayed by Bush. If that occurs, future budgets may bring back smiles to the faces of researchers in these disciplines.

\section{'Contrary' trade sanctions worry malaria researchers}

\section{Declan Butler}

Fears of breaching US export controls have forced a centre that was set up as an international resource for malaria researchers to refuse requests for reagents from scientists in Sudan and Cuba.

The Malaria Research and Reference Reagent Resource Center (MR4) in Manassas, Virginia, was established in 1998 to supply information and reagents to malaria researchers across the globe. But scientists at the centre realized last month that they risk fines of $\$ 11,000$ for each reagent sent to Cuba or Sudan. Both countries are covered by a US trade embargo on the grounds that they pose

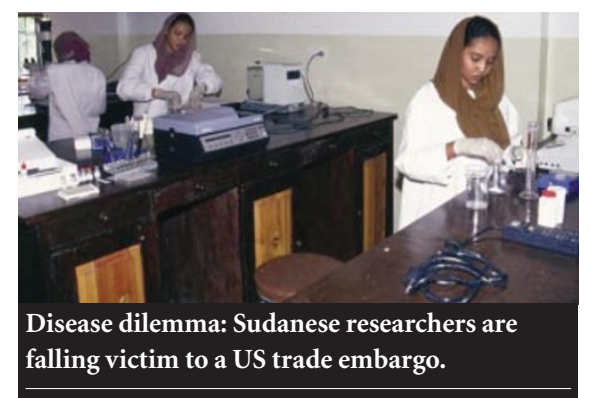

an "unusual and extraordinary threat" to US national security.

Sudan and Cuba are not the only nations subject to US trade embargoes, but they are most relevant to malaria research because of their geographical location. Although there are only a handful of malaria labs in each country, they are potentially important sites for clinical trials. Both countries have ongoing international collaborations.

David Walliker of the University of Edinburgh, who lobbied for the MR4's creation, says that had he realized the centre would be subject to US trade controls, he would have sought to have it funded by the World Health Organization, rather than the US government. "The embargo is contrary to the whole spirit and raison d'être of the MR4's establishment," he says.

The centre intends to ask the US Department of Commerce for an exemption from the embargoes. Research reagents do not at present qualify for exemptions granted to items such as food and medicine. Scientists fear that the MR4's future is at risk if the situation cannot be resolved. Alexandra Fairfield of the US National Institute of
Allergy and Infectious Diseases in Bethesda, Maryland, which funds the centre, fears that researchers may become reluctant to donate reagents to the centre - something the MR4 relies on to fulfil its functions.

Sudanese researchers have found their work hampered in other ways. In February, Moawia Mukhtar of the Institute of Endemic Diseases at the University of Khartoum had a paper on the parasitic disease onchocerciasis rejected by the US journal Clinical Immunology, which said: "Given the complexities of dealing with the export restrictions imposed by the United States government ban on trading with Sudan, and the severe penalties for running afoul of the law, we are not accepting contributions from Sudan."

Walliker wrote to the journal, protesting that the decision was contrary to the interests of international science. After taking legal advice, the journal decided this month that it could publish articles from Sudan, and has asked Mukhtar to resubmit. "It was so sad and humiliating for us," Mukhtar says.

http://www.malaria.mr4.org 